\title{
HUANDO: REFORMA AGRARIA Y DERECHO
}

Decir que la parcelación del fundo Huando, su posterior declaración de nulidad y la afectación total de las tierras que le pertenecían fueron problemas puramenie legales, es caricaturizarlos. Huando fue un problema político, como también lo es la Reforma Agraria, que no puede definirse sólo como la vigencia y aplicación de un conjunto de normas legales. Consecuentemente, Huando se encaró como un problema politico: se publicaron resoluciones directorales que por su jerarquía legal rara vez aparecen en el Diario Oficial, se emitieron comunicados oficiales y gremiales y la polémica saltó por varios días a la primera plana nacional.

A pesar de ello, el caso tuvo aspectos legales esenciales que quedaron opacados en la discusión. La magnitud de los intereses que en ese momento se jugaron y el innegable golpe de timón que sufrió el proceso de Reforma Agraria en la Costa a partir de alli, excedieron los linderos de las mil quinientas hectáreas del fundo. En Huando se decidió la suerte del proceso de parcelaciones por iniciativa privada llevado a cabo, entre los meses de octubre y noviembre de 1969, en los departamentos de Lima e Ica de acuerdo a las normas originales del Título IX del Decreto-Ley 17716 y su reglamento, el Decreto Supremo 165-69-Ap. Después de Huando se revisaron dichas parcelaciones y un apreciable número de ellas fue anulado por diversas irregularidades legales en su ejecución.

Nuestro interés en este artículo es estudiar los problemas jurídicos que se presentaron en este caso. La peculiaridad de los temas a tratar, nos dará posibilidad de efectuar algunas consideraciones teóricas.

En la complejidad del caso, sin embargo, no se discutió solamente sobre la validez de la parcelación. De hecho la demanda de Huando S. A. contra el Supremo Gobierno y el posterior recurso de apelación contra la sentencia de primera instancia, se fundamentaron en una serie de problemas administrativos y procesales que hacen de la Sentencia del Tribunal Agrario, una Ejecuioria de Derecho Administrativo y Procesal, antes que una sobre Derecho Agrario sustantivo. Por ello, nos referiremos a algunos de los múltiples pronunciamientos que, en estos aspectos, trae la resolución final del proceso.

\section{Las parcelaciones por iniciativa privada en el D.L. 17716}

La versión original del D.L. 17716, en el Título IX, traía una serie de normas sobre parcelaciones por iniciativa privada, que aparecieron en la Ley como la colaboración del Sector Privado para la ejecución del proceso de Reforma Agraria.

Básicamente se exigía que, bajo la supervigilancia y aprobación de la Dirección General de Reforma Agraria y Asentamiento Rural (DGRA-AR en adelante), los fundos se dividiesen en dos mitades. Sobre una de ellas se constituiría parcelas cuya extensión individual no sería superior al triple de la Unidad Agrícola Familiar (1) y sobre la extensión restante, parcelas que no excediesen el mínimo inafectable legislado para la zona (2). Se establecía, asimismo, que la DGRA-AR afectará los predios parcelados en contravención a lo establecido por la ley.

El reglamento fue dado en el mes de agosto de 1969 y en él se establecían el procedimiento y requisitos necesarios para efectuar las parcelaciones por iniciativa privada.

1. Para estos efectos, puede considerarse que la Unidad Agrícola Familiar mide 15 hectáreas.

2. Los mínimos inafectables varían entre 15 y 150 hectáreas según el lugar. 
Fue recién a mediados del mes de octubre de 1969 que se empezó a autorizar parcelación de fundos rústicos. El proceso se realizó casi exclusivamente en los departamentos de Lima e lca. Ya en los primeros dias de noviembre empezaron las protestas de los trabajadores que laboraban en las haciendas parceladas o en vías de parcelarse. El descontento fue en rápido aumento $y$, el 26 de noviembre de 1969, el Gobierno promulga el D. L. 18003 que modificaba sustancialmente las normas de parcelación.

El sistema sustitutorio, hoy incorporado al Título IX del Texto Unico Concordado del D. L. 17716, es bastante complejo pues legisla de manera diferente a los predios según su extensión y su destino económico (tierras de cultivo, de pastos para ganado, etc.). Basta decir que sólo se permite una parcela equivalente al mínimo inafectable, no debiendo exceder, las demás, de treinta hectáreas cada una. De igual manera, se exige transferir una parcela multifamiliar a los trabajadores estables $y$, casi la mitad de la tierra parcelada, a campesinos individuales, o agrupados en cooperativas, SAIS (Sociedades Agrícolas de Interés Social), etc.

Con estas nuevas reglas se pretendia hacer un reajuste a fin de que la ejecución de parcelaciones estuviese de acuerdo al espiritu de la Reforma Agraria implantada. El hecho de que a partir del D. L. 18003 no se haya efectuado ninguna otra parcelación, no hace sino corroborar que, lejos de ser una colaboración a la ejecución de la Reforma Agraria, las parcelaciones fueron utilizadas para evitar la aplicación de las causales de afectación (3).

\section{La parcelación del fundo Huando}

El 20 de octubre de 1969, Huando S. A. solicita a la IV Zona Agraria (repartición del Ministerio de Agricultura encargada de las actividades de Reforma Agraria en Lima), la aprobación de la parcelación del fundo Huando, de acuerdo a los documentos reglamentarios que acompaña a la solicitud, los que planteaban la creación de 48 parcelas sobre la extensión total del fundo (1,450 hectáreas aproximadamente).

3. Una investigación detallada de las parcelaciones efectuadas durante 1969 podría darnos una idea bastante exacta de los alcances de esta afirmación. Aunque explica la razón por la gue fueron parcelados muchos fundos, por el momento no tenemos base empírica para dar alcance general a esta afirmación.
Diez días después, cuando ya casi todos los trámites habian sido cumplidos, Huando S. A. presenta un recurso ante la IV Zona Agraria por el cual se compromete a subdividir cuatro de los 48 lotes originalmente planteados, para venderlos a algunos de los trabajadores estables del fundo. El 31 de octubre de 1969, al día siguiente de presentado este recurso, se emite la Resolución Directoral 031/69/DZ que aprueba la parcelación por iniciativa privada del fundo Huando.

Dos aspectos merecen resaltarse de esta resolución:

1. Se aprobaba la parcelación del Fundo Huando en 48 parcelas, de las cuales, cliatro excedían las máximas extensiones autorizadas por la ley: había una parcela de 162 hectáreas cuando el mínimo inafectable de la zona es de 150 hectáreas y las disposiciones de parcelaciones prohibían expresamente extensiones mayores a él en las parcelas resultantes $y$, por otro lado, existían tres parcelas que debiendo medir como máximo 45 hectáreas, llegaban a tener mayor extensión que ésa.

2. A continuación de la relación de 48 parcelas resultantes, se establecia el "compromiso" de los parcelantes de subdividir cuatro de las parcelas antedichas a fin de que fueran transferidas a trabajadores estables del fundo. Huando S.A. mantuvo permanentemente informada a la DGRA-AR sobre los avances del proceso y procedió a parcelar en base al cumplimiento de este compromiso.

En diciembre de 1969, Huando manifestó a la DGRA$A R$ que habia transferido todos los lotes de la parcelación y subparcelación prescritas por la R.D. 031/ $69 / D Z$ y que, en consecuencia, habia dejado de ser propietaria del fundo Huando. Comunicó, asimismo, que había enviado a esa repartición pública, copia de todos los contratos de transferencia de dominio a fin de que se les tomase debido conocimiento.

Puede afirmarse, en consecuencia, que la parcelación del fundo Huando y la posterior transferencia de sus parcelas a terceros (inscrita incluso en los Registros Públicos correspondientes), fueron totalmente ejecutadas en los términos de la R.D. 031/69/DZ.

\section{Declaración de nulidad de la parcelación}

El Sindicato de Trabajadores de la Hacienda Huando inició, desde la presentación de la solicitud de 
parcelación en 1969, una intensa lucha por lograr la afectación del fundo. La medida final que se tomó, fue una huelga indefinida que duró alrededor de seis meses y que dio lugar a una serie de apoyos laborales y a algunos incidentes de violencia que, a veces, terminaron en forma trágica.

Cuando la situación era ya politicamente insostenible, el día 4 de febrero de 1971, la DGRA-AR expidió la Resolución Directoral 098/71/DGRA-AR que declaraba nula la R.D. 031-69/DZ, que había aprobado la parcelación del fundo Huando en fecha 31 de octubre de 1969.

Huando S.A. interpuso Recurso de Revisión contra esta resolución ante el Ministro de Agricultura, el que fue declarado improcedente por éste, ya que según el Reglamento de Normas Generales de Procedimientos Administrativos (D.S. 006-67-JC), cuando la segunda instancia resolutiva tiene carácter nacional (y la DGRA-AR lo tiene), la vía administrativa queda agotada pudiendo plantearse, únicamente, la demanda de impugnación de resolución administrativa ante los tribunales competentes. En este caso, el competente para conocer del proceso era el Fuero Agrario.

\section{Impugnación Judicial de la R. D. 098/71/DGRA-AR de 4 de febrero de 1971}

Es asi como Huando S. A., con fecha 20 de mayo de 1971, interpone demanda de impugnación de la R. D. 098/71/DGRA-AR contra el Supremo Gobierno, ante el II Juzgado de Tierras de Lima.

La Ejecutoria que pone fin a este proceso judicial tiene que pronunciarse sobre diversos problemas planteados por la demandante en el recurso de apelación que interpuso contra la Sentencia de Primera Instancia. En las partes pertinentes del resumen anexo al presente artículo, pieden verse las argumentaciones planteadas por las partes, por el Dictamen del Fiscal del Tribunal Agrario, y las consideraciones hechas por el mismo Tribunal al emitir la Sentencia respectiva.

Nosotros, de todos los problemas que se presentan, trataremos tres:

- "La R.D. 098/71/DGRA-AR de fecha 4 de febrero de 1971 revivió un proceso fenecido".

- "La R. D. 098/71/DGRA-AR de fecha 4 de febrero de 1971 fue pronunciada por órgano incompeten- te y prescindiendo de las normas esenciales de procedimiento".

- "El art. 2o de la R. D. 098/71/DGRA-AR de fecha 4 de febrero de 1971 viola derechos adquiridos por terceras personas al amparo de la fe re. gistral".

Dentro del segundo problema señalado analizaremos también uno que no fue materia del proceso por los términos en que estuvo planteada la demanda, pero que subyace a todo el caso y que es, en realidad, la base del conflicto: la validez o nulidad de la R. D. $031 / 69 / D Z$ de fecha 31 de octubre de 1969 que autorizó la parcelación por iniciativa privada del fundo Huando.

\section{1. "La R.D. 098/71/DGRA-AR de fecha 4 de febrero de 1971 revivió un proceso fenecido".}

Como primer fundamento de su demanda contra la DGRA-AR, Huando S.A. sostiene que la R.D. 098/71/ DGRA-AR revivió un proceso fenecido.

Fundamenta esta argumentación en dos razones:

1. Huando S.A., la interesada, no apeló de la R.D. 03169/DZ de fecha 31 de octubre de 1969 dentro del plazo previsto por el art. $8^{\circ}$ del D.S. 16569-AP. (4)

Siendo ella la única interesada en el procedimiento de parcelación según las normas vigentes, la R.D. $031 / 69 / \mathrm{DZ}$ quedó consentida adquiriendo el carácter de irrevisable.

Ello queda respaldado, además, por el art. 228 de la Constitución que prohibe revivir procesos fenecidos.

2. La ejecución de la parcelación por iniciativa privada del fundo Huando, se llevó a cabo observando estrictamente los dispositivos legales vigentes y las normas contenidas en la R.D. 031/ $69 / D Z$ todo to cual se pone, paso a paso, en conocimiento de la DGRA-AR en forma oportuna.

La demandada, en el recurso de contestación a la demanda, contra-argumenta de la siguiente manera:

4. D. S. 165-69-AP, art. 8"-"Contra las observaciones formuladas (a la solicitud de parcelación) por la Dirección de Zona Agraria, el interesado podrá interponer apelación ante la Dirección General de Reforma Agraria y Asentamiento Rural, dentro de diez días de notificadlas éstas..." 
1. En este caso no procede citar el art. $228^{\circ}$ de la Constitución pues él se refiere a los procesos judiciales y no a los procedimientos administrativos.

2. El proceso de parcelación no estaba aún fenecido porque no se había escuchado ni resuelto los recursos presentados contra la R.D. 031/69/ $D Z$ por el Sindicato de Trabajadores del fundo Huando y que estaban procesalmente legitimados por las siguientes normas: Constitución, art. 60\%, Código Civil, art. IV del Título Preliminar; D.S. 006-67-JC, arts. 2\%, 4ㅇ, ọ y $88^{\circ}$.

3. Además de las dos razones anteriores, argumenta que en el Derecho Administrativo peruano no existen normas administrativas consentidas e irrevisables porque el art. $112^{\circ}$ del D.S. 006/67/JC permite anular resoluciones consentidas cuando agravien al interés público.

Las argumentaciones expresadas nos plantean varios problemas técnicos a resolver sobre la existencia de actos administrativos consentidos e irrevisables en nuestro Derecho. A fin de abordar en la forma más exhaustiva posible este tema, dividiremos su tratamiento en dos partes: existencia de actos administrativos consentidos e irrevisables en nuestro Derecho Administrativo, y su existencia en un caso de parcelación privada como es el caso Huando.

\subsubsection{Actos administrativos irrevisables en nuestro Derecho.}

Para analizar este punto, debemos comprender los alcances jurídicos del acto administrativo. El se desprende de la Potestad Administrativa que es aquélla por la cual los órganos administrativos del Estado, en ejercicio de las funciones que les asignan las leyes, aplican el Derecho a fin de dar cumplimiento a sus objetivos.

En función de la Potestad Administrativa, los actos administrativos están sujetos al principio de Legalidad, esto es, que deben ser acordes con el contenido de las leyes y que no pueden oponerse a ellas.

Es verdad que, en algunos casos, la Administración Pública, por mandato de la ley, asume también la Potestad Jurisdiccional. En estos casos, la Administración no aplica ejecutivamente las normas sino que interviene como juez en un conflicto, "dice Derecho" con los mismos alcances legales que el Poder Judicial. Por ello mismo, los actos que realice en esta función no serán actos administrativos sino actos jurisdiccionales, ya que la Doctrina está de acuerdo en calificar los actos no por la naturaleza del órgano, sino por la de su función:

"En la génesis del derecho positivo, obra esencial del Estado, hay tres fases principales, que corresponden a los distintos momentos de la realización del derecho, y que dan origen a las tres clases de funciones ya señaladas *, las cuales en sentido material se examinan no con referencia al órgano del Estado (distinción de orden subjetivo), porque éstas no pueden identificarse con ningún órgano **, sino en relación a la naturaleza de la actividad y al fin que, mediante ellas el Estado se propone realizar (criterio objetivo)" (5).

La naturaleza de la Potestad que en cada caso cumpla el órgano administrativo va a determinar también la estabilidad juridica de los actos que realiza. Si son jurisdiccionales podrán ser irrevisables siempre que queden consentidos; aunque nuestro derecho otorga la acción de contradicción ante el Poder Judicial. Si en cambio, los actos son administrativos, por el principio de Legalidad deberán ser siempre revisables.

Ello se debe a que, cuando hace uso de la Potestad Administrativa, el órgano es parte interesada desde que no asume función de Juez sino que actúa en cumplimiento de obligaciones o en ejercicio de derechos establecidos por las leyes, frente a terceros.

"En el estudio de la diferencia entre la administración y la justicia se ha dicho que el juez es el único que puede tomar decisiones que tengan la autoridad de la cosa juzgada. El administrador es el agente del Estado que no es legislador ni juez, vale decir, que actúa para ejecutar las decisiones del le-

* Las clases de funciones aludidas son legislación, jurisdicción y administración.

* * Nota a pie de página del mismo autor: "Es costumbre entre nuestros escritores juristas incurrir en la confusión que origina el atribuir a las manifestaciones inmediatas de la actividad del Estado una especial naturaleza derivada del concepto, en cierto modo dogmático de la división de los poderes, aún cuando no se conciba esta separación en sentido absoluto".

5. BIELSA, Rafael... Derecho administrativo.- Bs. As, 1964.- Libro II; Cap. I; pág. 180 del Tomo I. 
gislador y sus actos no pueden tener nunca la autoridad de la cosa juzgada" (6).

En este sentido es interesante resaltar aquel considerando de la Sentencia del Tribunal Agrario en el caso Huando, que establece que el principio de Legalidad de los actos administrativos recogido en el art. $112^{\circ}$ del D.S. $006 / 67 / \mathrm{JC}$ es un principio general de Derecho Administrativo que no puede desconocer ninguna ley o reglamento especial, porque el acto administrativo con vicio de nulidad no puede convalidarse ni por falta de recurso ni por transcurso del tiempo.

Este considerando es heterodoxo en relación al carácter eminentemente formalista de nuestro medio jurídico. Para nuestro Derecho, resulta evidente que una norma positiva impide la aplicación de un principio de derecho que le sea contrario. Los artículos XXI y XXIII del Título Preliminar del Código Civil, establecen claramente que el Juez debe aplicar la Ley y que, sólo en deficiencia de ella, procede la aplicación de los principios del derecho.

Sin embargo, la consideración que hace el Tribunal Agrario apunta no al cumplimiento de una norma especifica del orden positivo, sino a su mismo soporte: una disposición que diese carácter de irrevisable a los actos administrativos con vicio de nulidad, rompería el principio de Legalidad, y por tanto, entraria en contradicción con el fundamento que le da validez a ella misma: la legalidad de una norma legislativa no puede convalidar un acto contra-ley. Este caso nos lleva a una petición de principio en la base del orden juridico positivo donde la respuesta que ofrece el Tribunal Agrario, es una solución que perfecciona nuestra concepción sobre el conflicto entre la norma y el principio, adoptando un camino que nos salva de la paradoja pues, si se convalida la ilegalidad, ¿qué norma puede exigir obligatoriedad con verdadero sustento?

De lo dicho, podemos obtener estas dos conclusiones adicionales:

1. Que el art. $228^{\circ}$ de la Constitución no es aplicable a este proceso pues se refiere a aquellos procesos en los que se ejercita la Potestad Jurisdiccional.

No se trata de que, en este caso, la norma valga por su ubicación sistemática dentro de la Constitu-

6. DIEZ, Manuel María.- El Acto Administrativo.-Bs. As., 1961, Cap. X; p. 337. ción (el art. 228 ${ }^{\circ}$ está ubicado en el Título referente al Poder Judicial) y no por su contenido, como alega Huando S. A. en su recurso de apelación contra la sentencia del Juez de Tierras.

E] problema es otro y de carácter eminentemente teórico: una sentencia que pone fin a un proceso judicial "dice Derecho" y crea una norma para el caso concreto sub-litis, al margen de la posibilidad de que una ejecutoria se convierta en precedente de futuros fallos. En este sentido, la estabilidad de este tipo de resoluciones (actos jurisdiccionales) debe ser mantenida para las partes que se someten a la decisión judicial de un conflicto.

Es evidente que los órganos judiciales pueden emitir fallos no adecuados a ley, como en efecto lo hacen en muchos casos. Sin embargo, el hecho de que un organismo deba dirimir conflictos en la sociedad con carácter definitivo, es un requerimiento que justifica plenamente la existencia del proceso judicial fenecido. Si en algunos casos los fallos no son adecuados a ley, ello puede deberse más a un problema de inadecuación de la norma al caso concreto, o a un problema de criterio de interpretación, que a razones mezquinas o a mala intención.

En todo caso, es preferible salvar la importancia social de la función jurisdiccional otorgándole carácter de cosa juzgada, antes que quitar este principio por problemas que pueden solucionarse con una correcta elección de jueces o un perfeccionamiento de la norma positiva.

En definitiva, lo que hace necesaria la presencia de la institución del proceso fenecido en los órganos judiciales es que, al ejercer éstos la potestad jurisdiccional, no aplican el Derecho sino que lo "dicen", lo crean al unificar la norma genérica con el caso concreto y al solucionar finalmente un proceso. En la actividad de los órganos judiciales, la Legalidad no es un requisito sino un presupuesto.

"La cosa juzgada como atributo de los actos administrativos jurisdiccionales, o judiciales, declarados en juicio contencioso que adquieren estabilidad por decisión directa en controversia de la Administración Pública, en principio se funda en que ella supone juicio y emana de un acto jurisdiccional" (7).

Situación diversa se produce en los órganos que actúan en ejercicio de la potestad administrativa. Ellos

7. Ibidem.-- Libro X; cap. III; p. 358 del Tomo V. 
tienen derechos, atribuciones $u$ obligaciones, deben cumplir y/o hacer cumplir el Derecho: aplican las normas como parte interesada. En los actos administrativos, en consecuencia, la Legalidad no es presupuesto sino requisito. El órgano que ejerce potestad administrativa, a diferencia del que ejerce la jurisdicciorial, no crea sino que aplica la ley. De tal manera, sería absurdo amparar la validez de un acto administrativo ilícito mediante la institución de proceso fenecido. En consecuencia, es por la distinción de fines y funciones entre los órganos administrativos y los judiciales, y no por otra razón, que el art. $228^{\circ}$ de la Constitución no puede aplicarse a procedimientos administrativos.

2. La segunda conclusión anunciada consiste en que, para fines de determinar si un acto administrativo es o no revocable, es indiferente, desde el punto de vista teórico, el tenor de su contenido.

Huando S.A. alega en los fundamentos de su recurso de apelación, que hay dos tipos de actos administrativos que, una vez consentidos, no son revocables: los que declaran derechos y los de los órganos administrativos con jurisdicción.

Sobre los segundos ya hemos hablado: cuando un órgano administrativo actúa con potestad jurisdiccional, sus actos no son administrativos sino jurisdiccionales. Es un error de concepto considerarlos actos administrativos.

Sobre los primeros, los que declaran derechos, las consideraciones hechas anteriormente nos aclaran la situación: si lo que da calidad de proceso fenecido $y$ en consecuencia de irrevisabilidad, es la función social y legal que cumple un determinado órgano, es irrelevante para efectos de tal calificación el analizar el contenido del acto éectuado. Los actos administrativos, declaren o no derechos, están por su función sujetos al principio de Legalidad y, si son ilicitos, adolecen de un vicio de nulidad que desde el punto de vista teórico los invalida plenamente.

"Admitir que el acto administrativo que reconoce un derecho no sea revocable jamás, es algo tan absurdo que no merece refutación. Así, por ejemplo, si una jubilación está mal concedida por violación de ley, es la misma ley la que implícitamente auioriza la revocación puesto que al aplicarla se la ha violado" (8).

8. Ibidem.-Libro X; cap. III; p. 363 del Tomo V.
Esta argumentación, sin embargo, no basta para caracterizar debidamente el problema de los actos administrativos irrevisables en el derecho peruano. El art. $112^{\circ}$ del D.S. 006-67-JC establece: "En cualquiera de los casos enumerados en el artículo $45^{\circ}$ podrá declararse de oficio la nulidad de resoluciones administrativas, aun cuando hayan quedado consentidas, siempre que agravien el interés público".

La norma a que se refiere este artículo es la siguiente:

"Art. 45-_Son nulos de pleno derecho los actos administrativos:

a) Dictados por órganos incompetentes;

b) Contrarios a la Constitución y a las leyes y los que contengan un imposible jurídico;

c) Dictados prescindiendo de las normas esenciales del procedimiento, y de la forma prescrita por la ley".

Finalmente, todo ello debe concordarse con el art. 1 ㅇ del mismo Reglamento, que establece lo siguiente:

"Art. 1?-El Poder Ejecutivo, las entidades del SubSector Público Independiente y los Gobiernos Locales, ajustarán su actuación de orden administrativo a las prescripciones de este Reglamento, siempre que no se opongan a las leyes o sus reglamentos especiales".

Todo ello nos lleva a la siguiente conclusión: de acuerdo a la legislación peruana, todos los actos administrativos son revocables de oficio por la Administración Pública en las condiciones que señalan los artículos precitados, a menos que haya una norma especifica que conceda caráctér de irrevisables a actos administrativos determinados.

De otro lado, es claro que las normas citadas no hacen ninguna distinción entre los actos administrativos en función de su contenido. Por tanto, aun los actos administrativos que declaren derechos, podrán ser revisados de oficio de acuerdo a las normas señaladas. Esto nos hace ver que también desde el punto de vista del derecho positivo, resulta infundada la afirmación de Huando S.A. en el sentido de que los actos administrativos que declaran derechos son irrevisables.

Por razones de metodología de exposición, haremos un análisis detallado de las normas citadas, en la parte referente o competencia $\circ$ incompetencia de 
la DGRA-AR para anular la R.D. 031/69/DZ, con la R. D. $098 / 71 /$ DGRA-AR.

\subsubsection{Actos administrativos irrevisables en los casos de parcelación por iniciativa privada.}

$\mathrm{Ni}$ en la Ley de Reforma Agraria ni en sus reglamentos de parcelaciones por iniciativa privada, se ha * consignado norma alguna sobre la irrevisabilidad de los actos administrativos que se realicen en el procedimiento. En consecuencia, a falta de tales normas, se aplicará supletoriamente el D.S. 006/67/JC.

Sin embargo, no sólo esta "omisión" nos permite considerar el carácter revocable de las resoluciones que autorizaban las parcelaciones por iniciativa privada. El art. 113ㅇ del D:L. 17716, tanto en su versión original como en el Texto Unico Concordado, establece que serán afectados los predios parcelados en contravención a las disposiciones pertinentes de la legislación agraria (9).

Al no hacer distingos la mencionada norma, debemos inierpretar que sus alcances no se limitan sólo a aquellos casos en que los propietarios parcelaron sin pedir la autorización respectiva a la DGRA-AR, sino que aún cuando ella hubiere llevado adelante y aprobado el procedimiento respectivo, procederá la afectación siempre que se haya transgredido la ley. Esto, aun en el caso en que el procedimiento hubiese quedado consentido, pues tampoco allí se distingue.

Lo más importante para comprender el problema que nos ocupa es darnos cuenta que dicha afectación es una sanción a la ilegalidad de una parcelación y que, en el caso en que ella hubiera sido aprobada por una resolución administrativa, dicha resolución sería tácitamente anulada por el Decreto Supremo de afectación que es, además, norma de jerarquía superior.

De tal manera que, aun en las normas específicas sobre parcelaciones por iniciativa privada, encontramos una que autoriza a anular resoluciones administrativas dictadas en el procedimiento respectivo. Lo extraño de todo el proceso es que n! la defensa hecha por el Procurador General de la República en-

9. D. L. 17716, art. 113\%.-“La Dirección General de Reforma Agraria y Asentamiento Rural afectará los predios rústicos que sean fragmentados o parcelados en contravención a lo dispuesto por el presente Decreto-Ley. ..”. cargado del Ramo, ni la efectuada directamente por la DGRA-AR, hayan argumentado en base al artículo $113^{\circ}$ del D. L. 17716. Evidentemente, fue una omisión de importancia en el proceso.

Como consecuencia de todo lo dicho, podemos decir que tanto en nuestra legislación administrativa general como en la específica de parcelaciones privadas de Reforma Agraria, los procedimientos administrativos y sus resoluciones finales carecen de la estabilidad de los actos administrativos consentidos (el equivalente al status de "proceso judicial fenecido").

\section{2. “La R.D. 098/71/DGRA-AR de fecha 4 de febrero de 1971, fue pronunciada por órgano incompe- tenie y prescindiendo de las normas esenciales de procedimiento".}

La demandante argumenta esta afirmación de la siguiente manera:

1. La DGRA-AR es instancia procesal de apelación. De lo contrario carece de competencia para avocarse a la resolución de expedientes de parcelación.

2. $\mathrm{Ni}$ el artículo $149^{\circ} \mathrm{ni}$ el $150^{\circ}$ del D. L. 17716 dan competencia a la DGRA-AR para avocarse de oficio al conocimiento de expedientes resueltos por la instancia inferior (Zona Agraria) (10).

10. D. L. 17716, art. 149"-“"Corresponde a la Dirección General de Reforma Agraria y Asentamiento Rural del Ministerio de Agricultura, la ejecución de las acciones de transformación de la estructura de la tenencia de la tierra rústica, con personalidad jurídica, sólo para los efectos de la afectación, adquisición, expropiación y adjudicación de predios rústicos en aplicación de la legislación sobre Reforma Agraria, sin perjuicio de mantener la subordinación jerárquica correspondiente como dependencia del Ministerio de Agricultura".

D. L. 17716, art. 150\%.- "Además de las funciones señaladas la Dirección General de Reforma Agraria y Asentamiento Rural tiene las siguientes: percibir, administrar y rendir cuenta de los fondos que le sean asignados con fines de Reforma Agraria, evaluar el monto de los ingresos anuales y elaborar el plan anual de inversiones; dictaminar sobre los provectos de asentamiento rural que lleve a cabo el Estado o entidades particulares; apersonarse, en ejercicio de sus derechos, en toda clase de procedimientos cualquiera que sea el fuero al que corresponda, transigirlos o desistirse de ellos; imponer las multas que por violación o incumplimiento de sus normas señale el presente Decreto-Ley; cumplir y 
3. No se ha interpuesto el recurso de apelación $y$, por tanto, no hay competencia de la DGRA-AR para conocer el expediente.

4. En la R. D. 098/71/DGRA-AR se arguye que no han sido proveidos, dentro del procedimiento administrativo de parcelación, los escritos de los trabajadores, pero ellos no son parte en el procedimiento careciendo, en consecuencia, de legitimación procesal.

La demandada contesta con los siguientes argumentos, en su recurso respectivo:

1. Los trabajadores y el Sindicato tenian en el proceḍimiento de parcelación:

-Interés directo: porque son los beneficiarios potenciales del procedimiento expropiatorio.

-Interés personal: porque son interesados bien como Sindicato, bien como personas naturales.

- Interés actual y probado desde varios puntos de vista, especialmente laborales.

2. Al no haber normas sobre reclamaciones de terceros en el D. S. $165 / 69 /$ AP, el D. S. 006/67/JC funcionaba supletoriamente en virtud de su art. 116 (La DGRA-AR en este caso, citó equivocadamente el articulado. Debió recurrir al art. 19 del D.S. 006/67/JC, que es el que establece la norma sobre aplicación supletoria) (11).

Con esta argumentación, fundamentaba que los trabajadores $y / o$ el Sindicato de Huando sí tenían legitimación procesal en el procedimiento de parcelación, de acuerdo al art. $6^{\circ}$ del D. S. $006 / 67 / \mathrm{JC}$ que dice: "Para que el simple interés pueda justificar la titula-

hacer cumplir las resoluciones del Ministerio de Agricuitura $y$ del Tribunal Agrario; otorgar Jos contratos de adjudicación, así como los de adquisición de predios rústicos celebrados en cumplimiento de la Ley, empadronando a los adjudicatarios y propietarios, pudiendo delegar tales funciones en los respectivos funcionarios de Reforma Agraria; y las demás que le señale la Ley...."

11. D. S. $006 / 67 / \mathrm{JC}$, art. $116^{\circ}$.- "El presente Reglamento atañe a los actos administrativos o sea a las decisiones de las autoridades u órganos de la administración pública que, en ejercicio de sus propias funciones, resielven solbre intereses, obligaciones o derechos de las entidades administrativas o de los particulares respecto a ellas..." (Como puede apreciarse, el artículo procedente era el art. 10, citado anteriormente en este trabajo). ridad del reclamante se precisa que sea directo, actual y probado".

Las argumentaciones expresadas y otras que aparecen a lo largo del proceso, plantean problemas interesantes que discutir en este punto. Podemos resumirlos en dos: legitimación procesal de los trabajadores en el procedimiento administrativo de parcelación por iniciativa privada, y mecanismo de aplicación del art. $112^{\circ}$ del D.S. $006 / 67 / \mathrm{JC}$ al caso Huando.

\subsubsection{Legitimación procesal de los trabajadores}

En este punto la demandante argumenta con razón. Las normas sobre parcelaciones por iniciativa privada establecen un procedimiento administrativo de parcelación claro y preciso en lo que a interesados se refiere, pues a los únicos que legitima procesalmente es a los dueños del fundo a parcelarse.

Las características del procedimiento son las siguientes:

-El propietario debe presentar una solicitud de parcelación que será o no aprobada por la administración.

- La Administración tiene facultad de fiscalización de la forma y condiciones de efectivización de la parcelación, y la consiguiente capacidad resolutiva.

-Todo ello hace que el procedimiento adquiera el carácter de no contencioso.

Estas caracteristicas, voluntariamente asignadas por la Legislación al procedimiento, hacen absurda la argumentación de la DGRA-AR dentro de las normas procesales vigentes.

Al existir reglas de procedimiento de este tipo, se ha precisado quiénes pueden intervenir procesalmente $y$, en consecuencia, no cabe aplicación supletoria del D. S. 006/67/JC. Desde el punto de vista del derecho positivo, la argumentación de la demandada carece de validez.

Sin embargo, desde el punto de vista principista, consideramos que la DGRA-AR tiene razón.

Es evidente que en el procedimiento de parcelación (como en el de expropiación y tantos otros de Reforma Agraria), los campesinos tienen interés directo, personal y probado. Tal vez su derecho sea formalmente espectaticio pero, desde el punto de vista real, 
también posee actualidad: el campesino y el Estado saben qlie si un predio es afectado, el campesino será irremediablemente beneficiario y que en caso contrario será, también irremediablemente, un obrero asalariado para el cual la Reforma Agraria no trae más beneficio que una participación en utilidades difícilmente exigible, por la poca capacidad del Estado para fiscalizar un estricto cumplimiento de las normas que la instituyen y la contabilidad que hace efectivos sus derechos.

Por otra parte, nadie conoce mejor que el campesino la situación de cada fundo. El sabe si el dueño trabaja directamente, si produce con eficiencia, cuántas hectáreas tiene el predio, etc.

Salvo el caso de causal de afectación por condiciones contrarias a la legislación laboral, donde se ha creado un procedimiento en que se legitima procesalmente al trabajador, éste sólo participa en el proceso de Reforma Agraria desde la toma de posesión del fundo (12).

La DGRA-AR ha caído en cuenta de un problema real en los aspectos legales de la Reforma Agraria: el campesino, a pesar de tener interés, no es parte en

12. Vale la pena hacer un breve resumen del procedimiento de expropiación y entrega de las tierras a los campesinos. Normalmente, la aplicación de la Reforma Agraria se inicia con la declaración de Zona de Reforma Agraria que recae sobre un espacio geográfico determinado del país. Los propietarios tienen un plazo de sesenta días para suministrar a la DGRA-AR información sobre las extensiones de tierras de que son propietarios y demás características de sus fundos. Luego, la DGRA-AR empieza a estudiar la situación legal de cada fundo y las causales de afectación que le son aplicables. Inmediatamente se empieza a notificar las afectaciones a que hubiere lugar $y$, resueltas las apelaciones administrativas de los propietarios, si las hubiere, se dicta una norma de afectación de propiedad por el Poder Ejecutivo. Acto seguido se valoriza las tierras, se las expropia y se toma posesión de ellas, estableciéndose Comités Especiales de Administración donde los trabajadores nombren delegados. Teóricamente, estos Comités pueden durar hasta dos años, luego de los cuales se adjudica la tierra a los trabajadores individual o colectivamente. Como se puede apreciar, la participación de los trabajadores se produce en una etapa muy avanzada del proceso de aplicación de Reforma Agraria. Ello es tanto más grave si tenemos en consideración que no existen plazos perentorios para el cumplimiento de las diferentes acciones $y$ etapas. los procedimientos esenciales. Consideramos que debería serlo, pero ello no puede hacerse con los actuales marcos legales. Lo que procede es una iniciativa legislativa para que las normas se modifiquen $y$ legitimen procesalmente al campesino. Sería una modificación justa, realista y de carácter verdaderamente participacionista (lo que constituye uno de los valores políticos esenciales del Proceso Peruano, según sus voceros oficiales).

\subsubsection{Mecanismo de aplicación del art. $112^{\circ}$ del D.S. 006/67/JC al Caso Huando.}

Para determinar si la DGRA-AR era competente para revisar $y$, dado el caso anular la R. D. 031-69-DZ, es necesario revisar la aplicabilidad del art. $112^{\circ}$ del D. S. 006/67/JC y normas conexas al caso Huando. Ello tanto más, si consideramos que la Sentencia del Juzgado de Tierras y también la del Tribunal Agrario, legitiman la actuación de la demandada en base a dichas normas.

Podemos dividir el estudio de este tema en tres aspectos: aplicación supletoria del art. $112^{\circ}$ del D. S. 006/67/JC; cumplimiento de los requisitos del art. $45^{\circ}$ del D.S. 006/67/JC, y cumplimiento del requisito de agravio al interés público.

En cuanto a la aplicación supletoria se refiere, hemos ya analizado el problema en nuestro Derecho Administrativo y en el caso particular de parcelaciones por iniciativa privada, concluyendo que al no existir normas específicas sobre impugnación de estas resoluciones en la legislación, procede la aplicación supletoria del D.S. $006 / 67 / \mathrm{JC}$.

No podemos dejar de mencionar, sin embargo, la argumentación del Fiscal del Tribunal Agrario sobre este punto. Dice su dictamen que la Sentencia del Juzgado de Tierras (que amparaba la actuación de la DGRA-AR en el art. $112^{\circ}$ del D.S. 006/67/JC) desconocia el principio de garantía procesal. Veamos su argumentación: "La sentencia se basa en el art. 112 " del D.S. 006/67/JC. Es verdad que la norma es oscura, pero entonces, debe recurrirse a la supletoria y ésta es el art. 228 ${ }^{\circ}$ de la Constitución. La DGRAAR dice que no se aplica por estar bajo el título de Poder Judicial. Sin embargo, cabe recordar que el art. XIII del Título Preliminar del Código Civl señala que los jueces no pueden dejar de administrar justicia por deficiencia de la ley. En tal caso deben aplicar los principios generales del derecho". 
La primera atingenc:a debe referirse a la forma como se analiza el art. 112\%. La norma no es oscura sino simple y clara. Lo que crea dificultades es su aplicación al caso ccncreto. Es evidente que la resolución de este problema es algo compleja pero no puede esquivársela aludiendo a deficiencia técnica de la norma que, a nuestro juicio, no existe. Si el dictamen fiscal sirve para ilustrar la decisión del Tribunal, debe ser exhaustivo. Ello tanto más en un proceso de trascendencia.

Lo segundo, sin embargo, es apreciación más importante: resulta insólito que a una norma constitucional se le dé carácier de supletoria. Este es un criterio que desnaturaliza la función superior de ia Constitución en la estructura jerárquica del derecho positivo. Mal puede suplir la norma constitucional una simple norma adminisirativa como es el art. $112^{\circ}$ del D. S. $006 / 67 / \mathrm{JC}$.

Finalmente, la mención del art. XXIII del Título Preliminar del Código Civil es improcedente. En este caso no hay deficiencia de la ley sino problema de interpretación. Menos podria haberla habido dentro de la argumentación del Fiscal, si existia norma constitucional supletoria.

En cuanto a analizar si se cumplían los requisitos de nulidad que señala el art. 450 del D. S. 006/67/JC, se produce una situación curiosa: la R.D. 031/69/DZ sólo podía ser declarada nula si es que caía en alguno de los supuestos que seriala dicho artículo. En consecuencia, debía ser exiremo del proceso pronunciarse sobre la validez legal de la R. D. 031/69/DZ. La demandante alegó su legitimidad en todo momento, incluso en la demanda, y constituia parte de alguna de las múltiples pruebas que ofreció. Sin embargo, cuando en los considerandos de la Sentencia del Juzgado de Tierras el Juez emite opinión sobre la nulidad de dicha resolución, la demandante considera que existe una nulidad procesal al pronunciarse la sentencia sobre hechos ajenos a la controversia.

El Tribunal Agrario sostiene la validez de la Sentencia de Primera Instancia argumentando que su parte resolutiva se pronuncia sólo sobre la validez de la R. D. 098/71/DGRA-AR que era materia del proceso.

A nuestro juicio esta argumentación es equivocada. La validez de la R. D. 028/71/DGRA-AR fundada en la aplicación del art. $112^{\circ}$ del D. S. 006/67/JC exigía como condición necesaria ciue la R.D. 031/69/DZ fuese nula. La única manera de legitimar la aplicación del art. $112^{\circ}$ del D.S. $006 / 67 / J C$, en consecuencia, era analizar la legalidad de la R. D. 031/69/DZ dentro del proceso.

\subsubsection{Sobre la Legalidad de la R. D. 031/69/DZ}

Muchas han sido las pretendidas causales de nulidad de esta Resolución a lo largo del caso. No trataremos todas sino las que, a nuestro juicio, resultan valederas. Ellas son dos:

1. No cumplimiento de los máximos de extensión permitidos a las unidades resultantes de la parcelación. Como recordamos, la versión original del Título IX del D.L. 17716 establecia que, para parcelar, el fundo debía ser dividido en dos mitades de extensión equivalente. Una no podía tener parcelas mayores al triple de la Unidad Agrícola Familiar (o sea 45 hectáreas) y la otra no podía tener parcelas de extensión superior al minimo inafectable correspondiente al lugar (en la Costa, donde está Huando, dicho límite es y fue 150 hectáreas).

La R. D. 031/69/DZ autorizaba una parcelación en la cual una de las parcelas medía más de 150 hectáreas y tres de las chicas median más de 45 hectáreas.

Huando ha argumentado en favor de ello, diciendo que las parcelas que exceden de las medidas exigidas tienen en su perimetro bordes, caminos y huacas, cuya exiensión deducida deja en dichas parcelas áreas netas cultivables que encuadran con la extensión que prescribe el D. L. 17716.

Es verdad que ante esto el caso presenta hechos que son susceptibles de interpretación. Huando hace interpretación laxa mientras que el Juzgado de Tierras y la DGRA-AR la hacen restrictiva.

Esto vuelve discutible la eficacia de la nulidad por esta causal. Sin embargo, dos razones nos inclinan a defender la interpretación restrictiva:

- La primera es puramente formal. El D. L. 17716 no hace ningún tipo de distingo al hablar de los máximos de extensión permitidos a las parcelas en función de la calidad de superficie incluida dentro de su perímetro. En consecuencia, los máximos deberán ser respetados sin distinciones que la Ley no autoriza.

- Hay, no obstante, otra razón más de fondo: la Reforma Agraria según el art. 19 de la Ley, ha sido hecha para difundir la pequeña y mediana 
propiedad. Por ello no impone límites fijos sino que permite flexibilidad en la extensión de las unidades resultantes de la parcelación. Si consideramos además que las parcelaciones por iniciativa privada eran concebidas como una colaboración del sector privado a la realización de la Reforma Agraria, comprendemos mejor la improcedencia de la argumentación de Huando S.A.: se buscaba crear parcelas de la mayor extensión posible en su parcelación. No hay que dejar de hacer mención al hecho de que los excesos sobre las extensiones ordenadas por la ley sumaban, al momento de aprobarse la parcelación, más de seis Unidades Agrícolas Familiares mínimas (de 3 hectáreas cada una) en el valle de Huaral, donde está ubicądo Huando.

En otras palabras, por lo menos seis familias más se habrian beneficiado directamente con la parcelación del fundo, de haberse respetado las normas vigentes a esa fecha.

En todo caso, y aún cuando este punto no fue materia de resolución en la ejecutoria del Tribunal Agrario, es posible deducir del proceso que hay tendencia a asumir una interpretación restrictiva de la legislación frente al problema.

2. La segunda causal de nulidad de la R.D. 031/69/ $\mathrm{DZ}$, en nuestro concepto, es la siguiente: a continuación de la lista de parcelas aprobadas, la Resolución decía que Huando S.A. asumía el compromiso de subparcelar cuatro lotes en otros varios, de menor extensión, a fin de transferirlos a trabajadores del Fundo.

Dicha subparcelación fue realizada con posterioridad a la R. D. 031/69/DZ por Huando con conocimiento de las autoridades administrativas de Reforma Agraria, a las cuales también les fueron remitidas copias de los contratos de transferencia de las mencionadas parcelas.

Consideramos que ésta es una causal de nulidad irrefutable de la Resolución cuestionada.

Para comprender este punto, debemos analizar sumariamente el procedimiento de parcelación que existía en ese momento.

E) Reglamento de parcelaciones por iniciativa privada, aprobado por D.S. 165/69/AP, establecía que a la solicitud de parcelación, entre otros documentos, debian acompañar planos y memorias descriptivas de las unidades resultantes de la parcelación con la finalidad de que la DGRA-AR pudiese conocer, antes de aprobar, las condiciones técnicas de explotación de las parcelas resultantes: exiensión, tipo de tierras, accesos a caminos, accesos y condiciones de explota ción de la estructura de riego, eventuales servidumbres entre predios, etc. Todo ello con una saludable intención: lograr que la DGRA-AR pudiese observar las nuevas condiciones de uso de la tierra, haciéndola lo más racional y conveniente posible.

Ello nos lleva a otra consecuencia: la función de la DGRA-AR en el procedimiento de parcelación era de fiscalización $y$, por ende, la resolución aprobatoria era eminentemente unilateral, no pudiendo contener ningún tipo de cláusula contractual.

Pues bien, la R.D. 031/69/DZ rompió el principio de legalidad a que están sometidos los actos administrativos en dos puntos:

-El establecer un "compromiso" de Huando S.A. a subparcelar 4 de las parcelas equivalía a una cláusula contractual entre la propietaria y la Administración Pública, inadmisible en un acto administrativo resolutivo.

El organismo administrativo debía aprobar proyectos presentados y previamente estudiados, no crear compromisos y obligaciones futuras para los que no estaba facultado.

-La sub-parcelación, en realidad, implicaba una nueva parcelación que debía ser fiscalizada de acuerdo a las normas pertinentes, con la presentación y revisión técnica de los documentos que el D.S. $165 / 69 / \mathrm{DZ}$ exigía.

En otras palabras, la Administración Pública a través de la R. D. 031/69/DZ renunció a la obligación que las normas sobre procedimiento de atribuían.

Tan es así que la DGRA-AR nunca aprobó por Resolución los planos resultantes de la subparcelación. Simplemente fue informada de ellos por Huando S. A.

Tal vez podría argüirse que, en esta situación, sólo debia anularse la subparcelación, mas no toda la parcelación aprobada por la R. D. 031/69/DZ. Consideramos que este criterio es equivocado. La parcelación de un fundo es un proceso técnico y económico integral y no una suma de parcelas resultantes. Eso mismo se infiere de las normas pertinentes. Los problemas que pudiese generar una parcelación deficiente obligaron al D. L. 17716 y sus reglamentos a dar normas estrictas y detalladas. En consecuencia, mal 
puede inferirse la conclusión que criticamos. El apuro con que fue dada la R.S. 031/69/DZ es inadmisible desde el punto de vista legal. Lo que debió hacerse es observar la solicitud original de parcelación y esperarse a que Huando reformulase la operación y presentase los documentos exigibles para que, recién habiendo cumplido con el deber de fiscalización a que estaba obligado, el órgano administrativo emitiese la Resolución autoritativa correspondiente.

De manera que, como conclusión, consideramos que la R. D. 031/69/DZ adolecía de vicio de nulidad por ilegalidad en base a tres razones:

1. Haber autorizado una parcelación en la cual se reconocía a las unidades resultantes de la parcelación extensiones superiores a las permitidas por Ley.

2. El carácter contractual que asumía la R.D. 031/ 69/DZ era inadmisible en ella ya que debía ser un acto administrativo unilateral.

3. La DGRA-AR renunciaba a la fiscalización de la parcelación de acuerdo a ley, incumpliendo las normas vigentes.

\subsubsection{Agravio al Interés Público}

Como tercera condición para la aplicación del art. $112^{\circ}$ del D.S. 006/67/JC, teniamos la exigencia de que el acto administrativo cuya nulidad se declaraba fuese contrario al interés público.

La Sentencia del Juzgado de Tierras establecía que la R.D. 031/69/DZ había violado disposiciones de orden público y que, en consecuencia, iba contra el interés público.

La demandante, en su recurso de apelación, sostiene el siguiente punto de vista al respeco: "Por agravio al interés público debe y sólo puede entenderse la afectación de un bien o de un derecho del Estado, que representa y encarna a la sociedad en su conjunto. Es la usurpación, la violación o el perjuicio para la "cosa pública" (res pública) en contraposición con la "cosa privada" (res privada)".

De alli se concluía que el Juez de Tierras había confundido "disposiciones de orden público" con "interés público".

Menos explícito, el Dictamen Fiscal argumenta que hay lesión al interés público cuando se afecta a toda la colectividad y no a parte de ella.
Finalmente, la Ejecutoría del Tribunal Agrario da dos argumentos para interpretar este aspecto:

1. Que los conceptos de "interés público", "utilidad pública" y "necesidad pública" responden a imperativos de justicia y a exigencias socioeconómicas de la sociedad donde se aplican.

2. Que de los arts. 19 y $2^{\circ}$ del D. L. 17716 se desprende que la Reforma Agraria persigue la justicia social en el campo y forma parte de la política nacional de desarrollo, lo que interesa a toda la colectividad y no sólo a un sector o grupo $y$, por tanto, la parcelación de cualquier fundo es acto de interés general por lo que la violación de las normas de Reforma Agraria causan manifiesto agravio al interés público.

Todavía podríamos nosotros añadir un argumento más en ánimo de ser formalistas: si el art. $113^{\circ}$ del D. L. 17716 señala que serán afectados los predios parcelados en contravención a las disposiciones vigentes, y si el art. $5^{\circ}$ del mismo Decreto-Ley considera de interés social todas las causales de expropiación contenidas en la Legislación de Reforma Agraria, concluiremos que una Resolución que autoriza una parcelación por iniciativa privada no adecuada a ley afecta el interés social, ya que su vigencia impide la afectación del fundo.

D:scutir si "interés social" e "interés público" son conceptos equiparables nos parece bizantino. Es verdad que la norma del art. $112^{\circ}$ no concreta lo que debe entenderse por tal expresićn. Puede referirse bien al interés del Estado, bien al interés del grupo social. El Dictamen Fiscal, la Ejecutoria del Tribunal Agrario $y$, desde su punto de vista, la apelación de la demandante, prefieren con toda evidencia la segunda proposición, lo que consideramos acertado.

En efecto, el Estado es un ente jurídico que, en casos como el presente, tiene un interés propio, burocrático o político. Tiene personería propia y distinia a las personas naturales o colectivas de la soc'edad $y$, por tanto, sólo nominalmente su interés es el "interés público". En muchos casos, su posición es de claro enfrentamiento con los individuos, las personas jurídicas o el grupo social en su conjunto. Incluso, si como algunos tratadistas tales como Kelsen, sostenemos que Estado y Derecho son una identidad, decir que un acto administrativo es contrario a las leyes y que es contrario al interés público re- 
sulta una tautología. Por lo dicho, "interés público" en el art. $112^{\circ}$ del D.S. $006 / 67 / \mathrm{JC}$ debe entenderse referido al interés social, de la colectividad, como unánimemente sostienen las diferentes piezas del expediente citadas.

El problema de fondo es, sin embargo, diferente. Si bien Huando S. A., el Fiscal y el Tribunal coinciden en identificar interés público como interés de la colectividad, tienen criterios diferentes para determinar lo que es su contenido ideológico. Los dos primeros mantienen una posición típicamente privatista. Cuando Huando S. A. habla de que agravio al interés público es el agravio a la "Res pública" sólo podemos imaginarnos que el ejemplo típico en que se piensa es el bien de uso público: un camino, una calle, etc. El Tribunal Agrario, en cambio, aduce otros contenidos: imperativos de justicia, exigencias socioeconómicas de la sociedad, política nacional de Desarrollo, etc.

En definitiva, el problema es determinar cuál es el criterio para definir estos llamados "standards" (13), necesarios en Derecho, pero a los que se tiene tanto recelo en nuestro medio jurídico, probablemente por su menor concreción con respecto a otras normas.

Evidentemente, la forma concreta de los intereses colectivos es cambiante, alcanza progresivamente diversos grados de madurez en la evolución histórica de cada sociedad, depende de factores culturales (estructurales) y políicos (coyunturales), por lo que es dificil precisar su contenido en un momento y un espacio dados. Ello tanto más en un caso de reforma Agraria que, como hemos dicho, es preponderantemente político.

El proceso que tratamos vio darse en él las posiciones contrapuestas: o el mantenimiento de los criterios civilistas tradicionales (respondiendo a una conocida vocación estacionaria del Derecho para preservar la Seguridad Jurídica), o la innovación del Derecho asumiendo nuevas aspiraciones colectivas que se concretan en transformaciones sociales (lo que

13. “... esta noción no es otra que la de reglas que, en vez de formular una solución, dejan un cierto margen y apelan a la colaboración del juez o de la autoridad adiministrativa, acordándoseles un cierto poder discrecional: se les ha llamado "conceptos flexibles"... (Du Pas(quier, Claude... Introducción a la teoría general del derecho y a la filosofía jurídica). significa "inseguridad jurídica" por cambio en los postulados de aplicación del Derecho).

Dejando para después el análisis del problema doctrinal de la Seguridad Juridica (trascendental para la dinámica del cambio social, en relación con el Derecho), nos concretaremos al problema de elección de criterios de interpretación.

La mejor manera de abordar este asunto es hacer una breve descripción del funcionamiento de la interpretación de normas standard. Partimos de que son necesarias al Derecho porque, refiriéndose al buen criterio de la Administración y, en última instancia al del Juez, evitan una legislación casuística, por definición deficierite y esclerotizante. El standard empie$z a$ a ser interpretado $y$, en realidad, llenado de contenido a través de opiniones doctrinales y resoluciones concretas. Ellas van precisando sus alcances en relación a las peculiaridades que en cada problema se presentan $y$, a la vez, van perfilando lo que serán sus moldes de interpretación posterior.

Ello es manifiestamente claro en lo que a "interés público" se refiere. Hipotéticamente hablando, pensemos que durante diez años interpretamos el standard "interés público", desde la perspectiva del Estado Policía. La viclación de las normas tributarias, la obstrucción de vías públicas y la comisión de delitos serían los típicos agravios al interés público. Incluso, un intento estatal de imponer una planificación dirigista en la actividad económica, podría ser considerada como contraria al interés público, desde que a la Sociedad interesa preservar la libre iniciativa económica y empresarial de sus individuos (14). En este caso, los gobernantes no estarian aciuando de acuerdo a los principios que rigen el Derecho y la ideología social de ese momento.

Al cabo de los diez años, vamos a tener configurada la matriz de interpretación del standard. Tendremos que analizarlo desde un punto de vista liberal pues, en caso contrario, bastará una cita jurisprudencial o doctrinal, para que nuestra interpretación al-

14. Es evidente que en la hipótesis funcionan una serie de factores ideológicos distorsionantes: la idea del Estado Policía y la de libre empresa, son a menudo impuestas a un grupo social a través de la propaganda masiva y el control de los medios de información, aunque elo vaya contra sus intereses políticos objetivos. Ahora, sin embargo, sólo nos interesa analizar el problema de interpretación jurídica y no el político. 
ternativa sea considerada jurídicamente heterodoxa. $E_{s}$ verdad que en nuestro medio jurídico no se reconoce fuerza legal a la jurisprudencia o a la doctrina (salvo excepciones). Sin embargo, y sobre todo en este tipo de normas generales, se sigue mucho sus preceptos, tal vez porque no hemos sido acostumbrados a ser creativos en Derecho.

Siguiendo con nuestra hipótesis, supongamos que luego de transcurrido este lapso de diez años, ocurre un vuelco ideológico en el país y que el Estado pasa a asumir un rol dinámico en la vida económica. Se crean empresas públicas económicamente productivas y, lógicamente, se instituye algún tipo de planificación dirigida.

Ante estas nuevas circunstancias, se crea una legislación también novedosa que da marco institucional y operativo a estas nuevas perspectivas: se diseña un nuevo tipo de empresa (diferente a las privadas existentes hasta ese momento), se asignan sectores de actividad económica al Estado y, eventualmente, se pueden reestiucturar las normas sobre prioridad del crédito de la inversión, etc.

Toda la opción ideológica frente a la función social del Estado, ha sufrico una redefinición política que se refleja en el sistema legal. Las nuevas leyes derogarán y dejarán insubsistentes normas procedentes del Derecho anterior.

Sin embargo, la razón de ser de las reglas standard permanece y aun se hace más necesaria: el orden legal se enfrenta a nuevas perspectivas, menos exploradas que las anteriores $y$, por tanto, menos susceptibles de ser legisladas casuisticamente. El standard de "interés público" evidentemente perdurará. Lo importante es que también perdurarán sus interpretaciones jurisprudenciales y doctrinales $y$, como en el caso de la planificación dirigidas, serán evidentemente contrarias al nuevo modelo ideológico y a los nuevos contenidos normativos (que son consecuencia de los cambios ideológicos y políticos). Al hacerse evidente esta oposición, la interpretación del standard tendrá un efecto paralizante sobre la efectividad de las nuevas normas legales. No es raro encontrar ejemplos históricos de esta situación (15).

15. Los ejemplos a que aludimos, sobre todo jurisprudenciales, existen y son conocidos, pero no están sistematizados. Es un tema interesante y actual de investigación jurídica proceder a su recopilación e interpretación.
Si somos consecuentes con el principio de efectividad de las normas positivas, deberemos reconocer que es tarea de los hombres de Derecho (abogados, juristas, jueces, etc.) el readaptar sus criterios interpretativos a las nuevas realidades. No fue otra cosa la que sucedió cuando la Revolución Burguesa derrocó políticamente a la Autocracia y sentó las bases de un nuevo Derecho (el "Viejo Derecho" que hoy heredamos). Las condiciones sociales y políticas han cambiado y la necesidad de crear el nuevo Derecho actual es imperiosa.

Demás está decir que el argumento dado en el párrafo anterior para renovar los criterios de interpretación del Derecho, no está necesariamente reñido con una consideración valorativa del orden jurídico. En esta época de trabajo científico interdisciplinario, los descubrimientos de las ciencias sociales cuestionan la liberalidad de la ideología que sustentó un Derecho de espíritu civilista. Las valoraciones sociales se han transformado hacia una socialización creciente, los diferentes sistemas políticos y económicos asumen como indispensables reformas estructurales profundas $y$ el Derecho debe incorporar todo este movimiento modificando también sus valores. Desde este punto de vista las nuevas escalas axiológicas no resultan por definición injustas, salvo en comparación con los intereses prevalentes en un orden ya superado.

Esta digresión teórica nos permite regresar con fundamento a la consideración de las razones esbozadas por el Tribunal Agrario en el caso Huando. Lo que se ha hecho al defender que existe agravio al interés público cuando se autoriza una parcelación por iniciativa privada con vicio de llegalidad, no es otra cosa que incorporar nuevos criterios de interpretación para una antiguo standard. La reforma Agraria es una aspiración social que ha sido emprendida como parte de la planificación del desarrollo nacional.

Podremos discrepar de su orientación política o de los matices de su implementación pero tiene un irrecusable lugar en nuestra legislación positiva y en el proyecto de una nueva sociedad.

Con estas características ha pasado del campo ideológico a! legal $y$, por tanto, debe reconocerse el interés social que atribuye el art. 5 ? del D. L. 17716 a su causales de expropiación legisladas. Desde este punto de vista, creemos resulta improcedente la argumentación civilista de la demandante. Ella era válida dentro de los marcos de un régimen legal ante- 
rior, sustituido ahora por un orden positivo diferente que responde a nuevas exigencias sociales, y cuya efectividad no puede ser paralizada por criterios de interpretación que histórica y valorativamente le son ya ajenos.

\section{3. "El artículo 29 de la R.D. 098/71/DGRA-AR de fecha 4 de febrero de 1971 viola derechos ad- quiridos por terceras personas al amparo de la fe registral".}

El art. $2^{\circ}$ de la R.D. 098/71/DGRA-AR establecía textualmente lo siguiente: "Segundo.- Transcribir la presente Resolución a los Registros Públicos para los efectos legales correspondientes".

Resulta obvio que la intención de esta norma era lograr la cancelación de las inscripciones de la parcelación de Huando en el Registro de la Propiedad inmueble.

La argumentación de la demandante es la siguiente:

1. El art. 2ㅇ, al ordenar inscribir la R.D. 098/71/ DGRA-AR en el Registro Público, cuestiona cuando no anula, el derecho de los terceros adquirientes a título oneroso.

2. El D. L. 18833 (posterior a la Resolución cuestionada) recién establece que el Fuero Agrario es quien tiene competencia para declarar la nulidad de estas inscripciones. En consecuencia, la misma ley demuestra que antes, cuando se dio la R.D. 098/71/DGRA-AR. carecía de facultades para anular las inscripciones.

3. Por tanto, el art. $2^{\circ}$ es nulo por aplicación del inciso a) del art. $45^{\circ}$ del D.S. 006/67/JC.

(Según la disposición invocada para amparar la nulidad, ésta no proviene de violar derechos adquiridos, sino por vicio de ilegalidad y por falta de competencia del órgano administrativo para ordenar la cancelación del asiento. El inciso a) del art. 450 del D.S. 006/67/JC establece: "Son nulos de pleno derecho los actos administrativos:

a) Dictados por órganos incompetentes...").

La DGRA-AR, en su recurso de contestación a la demanda sostiene que el art. $2^{\circ}$ de la R.D. 098/71/ DGRA-AR no atenta contra la fe registral porque en él no se pide la anulación del asiento sino que se establece la transcripción de la Resolución al Regis- tro, pudiendo el Registrador denegar la inscripción en virtud de sus atribuciones.

Además sostiene que aun cuando el art. $2^{\circ}$ fuese nulo, ello no elimina el vicio de nulidad de la R.D. 031/69/DZ que aprobaba la parcelación de Huando.

El considerando respectivo de la sentencia del Juez de Tierras se pronuncia por la improcedencia de la nulidad del art. $2^{\circ}$ de la R. D. 098/71/DGRA-AR en virtud de que no ordenaba anular los asientos sino inscribir la Resolución en el Registro.

Finalmente, los considerandos de la Ejecutoria del Tribunal Agrario llegan a la misma conclusión en virtud de que la R.D. 098/71/DGRA-AR no dispone la inscripción de nulidad de parcelación en los Registros Públicos.

A pesar de que la intención del art. $2^{\circ}$ de la R.D. 098/71/DGRA-AR era, sin lugar a dudas, la de obtener la anulación de los asientos de parcelación o por lo menos su ineficacia legal, desde el punto de vista formal no ordenaba tal cosa sino únicamente la transcripción a los Registros Públicos. En consecuencia, nos parece válida la argumentación de la DGRA$\mathrm{AR}$ en su contestación a la demanda: el Registrador podia denegar la inscripción de la Resolución. El asunto se convertía en un problema de procedimiento registral. Además, aun suponiendo que tal norma fuese nula, no se acarreaba tamb:én la nulidad de la integridad de la R. D. 038/71/DGRA-AR, ni la convalidación de la R. D. 031/69/DZ.

Sin embargo, este problema formal no es el esencial dentro del conflicto planteado. El asunto de base es la permanencia del principio de la fe registral contenido en el art. $1052^{\circ}$ del Código Civil, en el campo de las parcelaciones por iniciativa privada y del Derecho Agrario en general.

EI D. L. 18833 aleja toda duda posible: desde que con la declaración de nulidad de parcelación, el juez debe ordenar la nulidad de los asientos respectivos, es claro que la fe registral no ampara a los compradores.

No queremos decir con ello que se produce una contradicción en el derecho positivo o que la desaparición de la fe registral en este campo sea asistemática en relación a nuestro orden jurídico. Al revés, pensamos que esta desaparición guarda coherencia con el resto de la legislación. 
Para comprender este postulado, tenemos que remontarnos a la razón de ser del principio de la fe registral. El nace como un mecanismo legal, accesorio al derecho de propiedad, para asegurar los intereses individuales de quien contrata, con quien se hace pasar por propietario. Tanto en el caso de la venta como del gravamen, el tercero podría verse perjudicado al efectuar el negocio, si carece de la seguridad de que está contratando con quien tiene el derecho de disposición sobre el inmueble. Para evitar este problema, el Derecho crea una presunción de pleno derecho y considera que quien aparece del Registro como propietario es el propietario, para todos los contratos de terceros sobre el bien, salvo que la causa de nulidad del derecho aparezca del mismo Registro (16).

El principio de la fe registral, en consecuencia, existe para dar seguridad a quienes adquieren derechos sobre inmuebles por contratos. Presupone. necesariamente, que el agente adquiere sus derechos en forma totalmente privada y que debe salvaguardarse su interés individual, frente a los intentos de fraude.

Cuando cambia el concepto de propiedad, cuando ella debe usarse en armonía con el interés social, cuando la propiedad de la tierra no depende ya del justo título sino también y fundamentalmente del trabajo y la conducción directa (17), las instituciones legales que como la ie registral, apoyaban un derecho de propiedad formal y iradicional. pierden ubicación en el ordenamiento jurídico.

Sería absurdo que por el solo hecho de existir un asiento registral, se frene un procedimiento de expropiación que, como hemos visto, tiene carácter de interés social. En Reforma Agraria el interés social prima sobre el individual, que es el defendido por la

16. Código Civil, art. 1052 - "Los actos que se ejecuten o los contratos que se otorguen por persona que en el registro aparezca con derecho para ello, una vez inscritos, no se invalidarán en cuanto a los que con ella hubiesen contratado por título oneroso aunque se anule el derecho del otorgante en virtud del título anterior no inscrito o de causas que no resulten claramente del mismo registro".

17. Estos aspectos han sido tratados en nuestro artículo Modificaciones al derecho de propiedad en la Legislación de Reforma Agraria, publicado en: DERECHO, 1972; Lima, Pontificia Universidad Católica del Perú; número 30. fe registral. En consecuencia, ésta no puede ser opuesta a la aplicación de la Reforma Agraria.

Ello no quiere decir que los individuos carezcan de seguridades frente al derecho de propiedad sobre tierras. Lo que pasa es que se asumen nuevas formas de protección, acordes a las nuevas ideas que sustentan el derecho positivo. En sustitución de la fe registral, el art. $3^{\circ}$ del D. L. 18833 establece el derecho preferencial de los adquirentes de parcelas en parcelaciones por iniciativa privada, a recibir en adjudicación las extensiones que conduzcan directamente hasta los limites de área autorizados (mínimos inafectables).

El Derecho se perfecciona y va adoptando las figuras más convenientes de acuerdo a sus normas. En Derecho Agrario, para los casos que tratamos, el derecho preferencial de adjudicación de las tierras que se conducen directamente es más coherente que el principio de la fe registral.

Por supuesto que podríamos discutir si la orientación adoptada por el Derecho Agrario en materia de propiedad es la más conveniente. Sin embargo, ésta es ya una discusión puramente política, ajena al campo jurídico. Lo que el Derecho debe hacer es sistematizar los elementos ideológicos incorporados a sus normas positivas, mudando lo que en él queda obsoleto y creando nuevas instiluciones más operativas. Este proceso, por lo demás, no es la primera vez que sucede en la historia jurídica. Las iransformaciones burguesas introducidas por la Revolución Francesa, sustituyeron todo un sistema legal que defendia los intereses de la aristocracia que la precedió.

Hoy es el Derecho Burgués y liberal el que queda obsoleto. Sus instituciones, que en algún momento y a un tipo de escuela jurídica parecieron inconmovibles, van siendo modificadas y derogadas paulatinamente.

\section{La Seguridad Jurídica}

De las consideraciones precedentes se desprende un tema adicional, más general y teórico, que ha adquirido carácter de principio esencial y oponible a las situaciones jurídicas que se le contrapongan: la Seguridad Jurídica.

Entre quienes han trabajado los aspectos jurídicos del Caso Huando, la Seguridad Jurídica se convierte en factor cuestionante de los resultados finales del 
caso en sus aspectos legales. Sobre todo, esta objeción se hace a dos niveles: por un lado, la violación del derecho de Huando S.A. a parcelar luego de aprobación formal y finalización del proceso de parcelación $y$, de otro, la violación de los derechos de los adquirentes de las parcelas resultantes, quienes vieron afectadas por el Estado las tierras que adquirieron.

Para trabajar este tema nos referiremos a la definición que de ella da Radbruch y que ha sido generalmente aceptada como una de las más logradas.

Radbruch nos la define como "... la seguridad del Derecho mismo..." (18) y ser̃ala cómo uno de sus requisitos principales es: "... (que) el Derecho positivo - si se quiere garantizar la seguridad juridicano debe hallarsé expuesto a cambios demasiado frecuentes, no debe hallarse a merced de una legislación incidental que de todo género de facilidades para troquelar cada caso concreto en forma de ley: los checks and balances - frenos y contrapesos- de la teoría de la división de poderes y la morosidad del aparato parlamentario son, desde este punto de vista, una garantía de la seguridad jurídica" (19).

Tras estas expresiones existe en verdad toda una concepción sobre los fines y caracteres esenciales del Derecho. Trataremos de hacerla evidente a través de dos ideas centrales.

1. La Seguridad Jurídica es la seguridad del Derecho mismo. Generalmente se ha entendido por Seguridad Jurídica la invulnerabilidad por ley posterior, de un derecho legalmente adquirido por un sujeto en un momento determinado. Tradicionalmente, la Seguridad Juridica ha ido estrechamente ligado a otros conceptos doctrinales que se le ensamblan complementariamente: la irretroactividad de la Ley y el derecho subjetivo.

Aunque estos tres conceptos mantienen su propia individualidad de manera que no se los pueda hacer equivalentes, apuntan a un mismo objetivo: evitar que el interés de una persona, amparado en un momento determinado por el Derecho, sea perjudicado o elimlnado después por el mismo Derecho.

18. RADBRUCH, Gustav, Introducción a la Filosofía del Derecho; México, Fondo de Cultura Económica, $3^{\text {a }}$ edición, 1965, pág. 40.

19. Loc. cit.
Cuando Radbruch dice que la Seguridad Juridica debe ser la Seguridad del Derecho mismo, por tanto, más que describir una realidad formula una aspiración que se expresaba tácitamente en las elaboraciones anteriores a él: el Derecho debe ser el salvaguarda de esos intereses, debe ser su tarea esencial protegerlos; el Derecho debe ser seguro en si mismo, no por sí, sino para aquellos a quienes prescribe conductas.

Radbruch entiende que sólo así el Derecho podrá cumplir su papel normativo a cabalidad: sólo si el Derecho es seguro en sí mismo podrá dar seguridad.

Tras esta elaboración hay, evidentemente, algunos contenidos que vale la pena poner de manifiesto.

El más importante es la defensa del interés individual. El Derecho debe defender estos intereses, cuando han sido válidamente convertidos en derechos de acuerdo a la ley vigente, y son oponibles a cualquier nueva circunstancia.

El Derecho así visto, adquiere una connotación eminentemente privatista pues legisla a individuos que deben ser defenddios unos de otros.

Por supuesto que existen excepciones a este principio aun en el Derecho Tradicional. Un buen ejemplo es la expropiación por causa de utilidad pública que, ni aun en los regímenes más liberales ha dejado de existir. Claro que el contrapeso del interés privado y el público, varía con el tiempo. Antes sólo se expropiaba en casos excepcionales, pero sin llegar a convertirse, la expropiación, en un instrumento de política de uso frecuente. Normalmente el interés privado estaba por encima del público y sólo en casos excepcionales como la utilidad pública, habia una inversión del criterio. Esto quiere decir que cuando el interés público primaba, el problema de la "inseguridad jurídica" no existía.

De acuerdo a este planteamiento, el problema de Seguridad Juridica se mueve en el ámbito del interés privado y del Derecho Privado que lo ampara. Esto se confirma con dos hechos de la historia del Derecho:

-EI concepto de Seguridad Jurídica se ha desarrollado en las ramas privatistas del Derecho.

-Nunca se ha considerado como inseguridad juridica, diversas medidas que atentan contra el interés público. Un buen ejemplo es el constante 
otorgamiento de extensiones tributarias. En el país, la mayoría de los impuestos van teniendo progresivamente una disminución en el quanto de la base imponible que, luego de un lapso, obliga a reordenar y sustituir el impuesto. Semejantes al caso anterior son las amnistías tributarias que también generan al Fisco menores ingresos de los previstos.

En ninguno de los dos casos, como en tantos otros semejantes, se arguye falta de Seguridad Jurídica. No importa que el Estado haya creado impuestos a fin de sustentar sus gastos, necesarios para la Sociedad. La erosión que se produce a nivel macroeconómico, en la base imponible sobre la que se tributa, no genera inseguridad al Fisco y a la Sociedad, a pesar de que produzca, como lo ha hecho (sobre todo la exención), crisis económicas considerables.

En consecuencia, podemos concluir que la seguridad jurídica no es la seguridad del Derecho mismo sino, a lo sumo, de parte de él. Sólo se argumenta inseguridad cuando se afecta intereses individuales dentro del régimen del Derecho Privado.

2. El segundo problema que aparece de las citas de Radbruch es que la seguridad jurídica es un principio eminentemente conservador. La alusión a la morosidad de los órganos legislativos no puede ser más explícita: mientras menos cambie el Derecho, más cumplirá con dar seguridad.

Este aspecto de la institución que tratamos es incompatible con el carácter dinámico de la sociedad y con la necesidad de profundas transformaciones. Si ellas son necesarias, el Derecho se les opondrá en aras de mantener seguridad. Inversamente, si queremos que el Derecho contribuya a efectuar procesos de cambio, la Seguridad Jurídica debe ser relativizada como lo fue, una vez más, la seguridad de la aristocracia con la irrupción del Derecho Burgués.

Estas apreciaciones, por otra parte, nos muestran los estrechos vínculos que tienen entre sí instituciores aparentemente disímiles como Seguridad Juridica y $\mathrm{Fe}$ Registral.

Ubicadas en campos y niveles diferentes, en el fondo responden a un mismo fundamento valorativo: defender intereses individuales y propugnar un carácter conservador del Derecho.
Puede ser que en teoria esta descripción no sea exacta. Es posible que, aún un Derecho de cambio necesite recoger de alguna manera sus aspectos fundamentales. Sin embargo, desde el punto de vista operativo funcionan así $y$, por tanto, ese es el destino real que les ha asignado nuestro sistema legal.

Por el hecho de ser fruto de un determinado sistema jurídico, al responder a determinados esquemas valorativos, la vocación de perpetuidad que se les asigna resulta errada o politicamente significativa. Al cambiar los esquemas valorativos que se incorporan a las normas positivas (interés social, etc.), todo el andamiaje teórico que conforman estos principios, quedan sin base $y$, por tanto, debe ser sustituido o derogado.

\section{La teleología de los métodos de interpretación}

Un último tema que nos permiten el caso Huando y las consideraciones teóricas que hemos expuesto es que, en cualquier caso, los criterios interpretativos son estrechamente dependientes de los intereses que se busca defender.

Quisiéramos diferenciar lo que son métodos de interpretación, de lo que aquí llamamos criterios. Por métodos entendemos los tradicionales: literal, lógico, analógico, sistemático, etc.

El criterio de interpretación es otra dimensión del problema. Es el elemento de decisión mediante el cual nosotros preferimos un método u otro para aplicar la ley a un caso determinado.

En la teoría, o en el ejemplo llamado "de laboratorio" la aplicación de las normas no tienen problema. En los hechos cotidlanos, sin embargo, costantemente nos encontramos con que los supuestos de la norma son imperfectamente cumplidos, por exceso o por defecto de los hechos o situaciones.

De esta manera, los interesados proceden a aplicar el Derecho por diferentes apreciaciones de hechos y su relación con supuestos jurídicos. La existencia nada escasa de interpretaciones contradictorias y respetables no procede muchas veces sino de haber utilizado un distinto método de interpretación, siendo de resaltar que en Derecho nunca se ha dado ni podrá darse, normas precisas sobre elección y jerarquización de métodos.

En el caso estudiado del standard "interés público" se dio con toda claridad esta contradicción, Huando 
S. A. hace una interpretación típicamente formalista y literal. El interés público será el de toda la colectividad y no el de parte de ella. En consecuencia, en la parcelación de un fundo, no hay interés público sino, a lo sumo, un interés grupal.

El Tribunal Agrario, en cambio, hace una interpretación finalista en virtud de lo que se ha dado en llamar el espíritu de la norma. Del hecho de que los artículos 19 y $2^{\circ}$ del D. L. 17716 señalen que la Reforma Agraria persigue la justicia social en el campo y forma parte de la política nacional de desarroIlo, deduce que cada acción de Reforma Agraria reviste interés público.

Es de notar cómo existe una toma de posición ideológica en la base de cada posición, que condiciona el método de interpretación a elegir. Ello nos lleva a tres conclusiones importantes:

1. La importancia del contenido ideológico para la aplicación del Derecho es fundamental. La misma norma puede aplicarse e interpretarse de manera totalmente diferente por quienes tienen apreciaciones ideológicas disímiles *

2. El proceso de aplicación del Derecho, al menos en este tipo de casos y otros similares, tiene más de subjetiva que de objetiva (calificación que corresponde al carácter técnico o científico que se atribuye en muchos casos al Derecho).

3. Todo ello demuestra que la aplicación del Derecho es tanto o más importante que el enunciado abstracto de la norma para la determinación de los contenidos del Derecho. En consecuencia, es imprescindible una revaloración de la importancia de las interpretaciones doctrinales y jurisprudenciales como fuentes del Derecho. En nuestro Sistema, si bien se les reconoce validez en la praxis jurídica, se les niega ese carácter a nivel de la teoría en la mayoría de las ramas de Derecho.

Sin embargo, no sólo existen estos dos tipos de interpretación (formalista y finalista). En el caso de "interés público" analizado, ambas posiciones (Huando S.A. y Tribunal Agrario) se desprenden de una

* Por supuesto que lo ideológico no es la única variab.e que lleva a interpreticiones diferentes. También lo hacen la diferencia de intereses o la de fines entre otras. misma norma positiva apreciada en forma diferente. Hay otros casos, no obstante, donde las conclusiones jurídicas no parten de una norma positiva sino de una elaboración doctrinal o principista que a veces cubre vacios de la ley y a veces va contra las normas positivas. Tal es el caso de Huando S.A. cuando señala que hay dos tipos de actos administrativos que no son revocables una vez consentidos: los que declaran derechos y los administrativos jurisdiccionales; también es el caso del Tribunal Agrario al decir que la legalidad del acto administrativo es un principio de Derecho Administrativo que no puede desconocer ninguna ley o reglamento especial.

Este criterio de interpretación va más allá que el formalista y el finalista porque llega a sustituir una norma positiva o a crear otra semejante. En este caso, la importancia de la aplicación de Derecho como creadora de contenidos jurídicos se hace más patente aún.

Todas estas consideraciones nos llevan, en última instancia, a considerar la relatividad que en el Derecho encierra la selección de los medios técnicos para su aplicación, la importancia que dentro de ello tienen los elementos ideológicos de quien aplica y, como corolario, la importancia que tiene la aplicación de Derecho en un proceso de cambio social.

Esto último nos es de especial interés. Si asumimos que un proceso de cambio social se va a regir por leyes que le son anteriores y con distinta orientación política, ante la imposibilidad de cambiar de golpe un sistema legal, concluiremos que la forma de aplicación de este Derecho anterior, variará en las nuevas circunstancias. Será la única forma de evitar contradicciones irresolubles en la legislación.

Algo de esto se ha avanzado en la doctrina al decir que la llamada "Voluntad del Legislador" no es una buena vía para interpretación, entre otras razones, porque las concepciones sociales varían en el tiempo. Sin embargo, esto se ha referido siempre a las variaciones lentas y automáticas de la sociedad, no aplicándose nada parecido a lo que constituyen cambios sociales inducidos y más profundos.

En el Caso Huando hay bastantes ejemplos analizados que contrastan criterios de interpretación. Sin embargo, no son más que ejemplos. Una investigación más rigurosa y amplia de este tema, permitiría desarrollar y descubrir una serie de mecanismos no estudiados aún en el cambio del Derecho. 


\section{RESUMEN DEL EXPEDIENTE DE HUANDO S. A. CONTRA EL SUPREMO GOBIERNO SOBRE \\ IMPUGNACION DE LA RESOLUCION DIRECTORAL 0987/1/DGRA-AR}

\footnotetext{
-Con fecha 20-5-71, Huando S. A. interpone demanda contra el Supremo Gobierno por impugnación de la Resolución Directoral No 098-71-DGRA-AR, recaudando algunas de las pruebas que se ofrecen en la demanda.
}

Los fundamentos de la nulidad ipso jure de la resolución que alega el demandante son los siguientes:

La Resolución revivió un proceso fenecido.

La Resolución fue pronunciada por órgano incompetente y prescindiendo de las normas esenciales de procedimiento.

El artículo segundo de la resolución impugnada atenta contra la fe registral sancionada en el artículo $1052^{\circ}$ del Código Civil. El texto del artículo segundo de la Resolución impugnada es el siguiente: "Segundo.- Transcribir la presente Resolución a los Registros Públicos para los efectos legales correspondientes".

1. La Resolución 098/71/DGRA-AR revivió un proceso fenecido.

1.1. La Resolución Directoral № 031/69/DZ de 31-10-69, que aprobó la parcelación del fundo Huando y que se pretende declarar nula por la R.D. 098-71-DGRA-AR, no fue apelada por el interesado dentro del término previsto en el ari. 8? del D. S.16 5-69-AP y, por ello, quedó conseniida adquiriendo el carácter de irrevisable.
1.2. La parcelación fue integramente ejecutada en los términos de la R. D. 031-69-DZ -válida en fondo y forma según el demandante$y$ en fecha 5-12-69 se informa a la Dirección General de Reforma Agraria que sólo falta formalizarse dos contratos de compra-venta de parcelas cuyas minutas ya existian. Con fecha 21-12-69 se indica que ya han sido vendidos todos los lotes.

1.3. Con fecha 4-2-71, la R.D. 098/71'DGRA-AR declara nula e insubsistente la R.D. 031/69/ $\mathrm{DZ}$ pretendiendo revivir un proceso fenecido que atenta contra el art. $228^{\circ}$ de la Constitución.

2. La R. D. 098/71/DGRA-AR fue pronunciada por órgano incompetente y prescindiendo de las normas esenciales del procedimiento.

2.1. La DGRA es instancia procesal de apelación. De lo contrario carece de competencia para avocarse a la resolución de expedientes de parcelación.

2.2. $\mathrm{Ni}$ el art. $149^{\circ}$ ni el $150^{\circ}$ del D. L. 17716 dan competencia a la DGRA para abocarse de oficio al conocimiento de expedientes resueltos por la instancia inferior (Zona Agraria).

2.3. No se ha interpuesto el recurso de apelación y, por tanto, no hay competencia de la DGRA para conocer el expediente.

2.4. Se arguye que no se ha proveído dentro del procedimiento administrativo de parcelación los escritos de los trabajadores, pero ellos no son parte en el procedimiento, careciendo de legitimación procesal. 
3. El art. $2^{\circ}$ de la R. D. 098/71/DGRA-AR viola derechos adquiridos por terceras personas al amparo de la fe registral.

3.1. El art. $2^{\circ}$, al ordenar inscribir la R.D. en el Registro Público, cuestiona, cuando lo anula, el derecho de los terceros adquirentes a título oneroso.

3.2. El D.L. 18833 recién establece que el Fuero Agrario es quien tiene competencia para declarar la nulidad de inscripciones. En consecuencia, la misma ley demuestra que antes, cuando se dio la R. D. 098/71/DGRA-AR, carecia de facultades para anular las inscripciones.

3.3. Por tanto, el art. $2^{\circ}$ es nulo por el art. $45^{\circ}$ del Reglamento de Normas Generales de Procedimientos Administrativos en su inciso a).

(Según la demandante, la nulidad no proviene de violar derechos adquiridos sino por ir contra la ley y por falta de competencia).

- Con fecha 25-5-71 el juez decreta la admisión de la demanda, mandando notificar al Procurador General de la República en el Ramo de Agricultura y a la Dirección General de Reforma Agraria y Asentamiento Rural aceptándose diversas pruebas y rechazando otras por no ser instrumentales.

En la misma fecha se notifica la Resolución a Huando S. A. por cédula y al Procurador y la DGRA por cédula y por Correo.

-Con fecha 31-5-71 el Procurador General de la República en el Ramo de Agricultura contesta negando la demanda y ofreciendo diversas pruebas.

-Con fecha 1-6-71 el Juez da por absuelto el trámite y por aceptada la prueba ofrecida.

-Con fecha 1-6-71 Huando presenta recurso de apelación contra la Resolución del Juzgado de 25-5-71 en la parte que rechaza determinadas pruebas por impertinentes al no ser instrumentales. Se solicita la alzada en ambos efectos en virtud del art. 1097\% inc. $4^{\circ}$ del Código de Procedimientos Civiles.

-Con fecha 1-6-71 el Juzgado concede la apelación en un solo efecto.

-Con fecha 1-6-71 Huando deduce la nullidad del auto (según el recurso porque en rigor se trata de un decreto) admisorio de la instancia al haberse emplazado a la Dirección General de Reforma Agraria y Asentamiento Rural cuando ella, según la legislación vigente, forma parte del Ministerio de Agricultura $y$, en consecuencia, será representada en juicio por el Procurador respectivo.

-Por auto de 1-6-71 el Juez deniega la nulidad del admisorio de la instancia en base a nutrida jurisprudencia del Tribunal Agrario en el sentido de que la DGRA-AR tiene personeria suficiente para apersonarse en cualquier tipo de procedimiento.

- Con fecha 4-6-71, Huando apela del decreto que rechaza la nulidad del admisorio.

-Con fecha 7-6-71, el Juez emite un auto denegando la apelación por no versar sobre sentencia o resolución que pone fin a un procedimiento.

-Con fecha 8-6-71 el Procurador presenta un recurso fundamentando su contradicción de la demanda en los siguientes términos:

1. La referencia al art. $228^{\circ}$ de la Constitución resulta totalmente impertinente pues, este artículo, se refiere a procedimientos judiciales y no a administrativos como el de Huando.

2. La DGRA es competente para estudiar este expediente administrativo de parcelación del Fundo Huando porque:

2.1. La R.D. No 098-71-DGRA-AR ha sido dictada conforme a los arts. $1123^{\circ}$ inc. $3^{\circ}$ del Código Civil y $455^{\circ}$ inc. c) del D.S. 006-67JC de 11-11-67.

2.2. Porque el expediente administrativo había sido elevado a su conocimiento por la IV Zona Agraria tal como se aprecia del Memo Nọ 34-D/IV/DZ/71 de 28-1-71.

3. La demandante señala que el art. $2^{\circ}$ de la R.D. 098/71/DGRA-AR configura despojo contra los compradores de parcelas, pero no toma en cuenta que el art. $3^{\circ}$ del D. L. 18833 les da derecho preferencial a la adjudicación de las parcelas que vengan conduciendo directamente.

Por tanto, no hay nulidad ni por revivir proceso fenecido, ni por incompetencia ni por atentar contra la fe registral.

-Con fecha 11-6-71 Huando solicita copias certificadas de diversas piezas del proceso a fin de ocu- 
rrir en queja ante el Tribunal Agrario por la Resolución de fecha 7-6-71 en que se deniega la apelación interpuesta.

- Con fecha 11-6-71, la DGRA contesta la demanda negándola en todas sus partes con los siguientes argumentos:

1. La DGRA no ha revivido un proceso fenecido.

1.1. Citar el art. 228 de la Constitución no procede pues éste se refiere a los procesos judiciales y no a procedimientos administrativos.

1.2. El proceso no estaba fenecido porque aún no se había escuchado ni resuelto los recursos del Sindicato que estaban procesalmente legitimados por las siguientes reglas: Constitución, art. 60\%; Código Civil, art. IV del Título Preliminar; D. S. 006-67-JC. arts. 2 ㅇ, 4 ㅇ, 5 \% y $88^{\circ}$.

1.3. Dice la demandante que no hubo apelación de la R.D. 031/69/DZ por ella, que era la única legitimada para hacerlo. Ello es falso porque, de acuerdo al art. $106 \%$ del D.S. 006-67-JC, el recurso de fecha 3-11-69 presentado por los trabajadores de Huando, debe considerarse apelación.

1.4. Además, no se ha revivido ningún proceso fenecido porque las normas de procedimiento administrativo permiten anular Resoluciones consentidas cuando agravien el interés público (art. 112ㅇ del D.S. 006-67-JC).

2. La R. D. 098/71/DGRA-AR no se dictó por órgano incompetente y prescindiendo de las normas esenciales de procedimiento.

2.1. Los trabajadores y el sindicato tenían en el procedimiento de parcelación:

2.1.1. Interés directo: porque son los beneficiarios potenciales del procedimiento expropiatorio.

2.1.2. Interés personal: porque son interesados bien como sindicato, bien como personas naturales.

2.1.3. Interés actual y probado desde varios puntos de vista, especialmente laborales.
2.2. Al no haber normas sobre reclamaciones de terceros en el D. S. 165-69-AP, el Reglamento de Normas Generales de Procedimientos Administrativos funcionaba supletoriamente en virtud de su art. $116^{\circ}$.

3. No se atenta contra la fe registral porque:

3.1. No se pide anulación de asiento sino transcripción de resolución que el registrador puede denegar.

3.2. Aun cuando el art. $2^{\circ}$ de la R. D. 098/71/ DGRA-AR fuese nulo, ello no elimina el vicio de nulidad de la R.D. 031/69/DZ que aprobaba la parcelación de Huando.

- Con fecha 28-6-71, Huando solicita se le franquee por mesa de partes el expediente administrativo de parcelación que obra en el expediente en calidad de prueba, y que cuando el proceso se encuentre en estado de resolver, se autorice al Letrado a informal verbalmente ante el Juez de la causa.

- Con fecha 28-6-71 el Juez ordenó poner a conocimiento de Huando el expediente administrativo solicitado y tener presente oportunamente el pedido de informe oral.

- Con fecha 5-7-71 se presentan ante el Juzgado mediante un recurso, Zósimo Torres Claros y otros, a nombre propio y como dirigentes del Sindicato de Trabajadores y Braceros de la Hacienda Huando, solicitando se les considere como parte en el juicio y exponiendo diversos puntos de vista sobre la parcelación del fundo Huando.

- Con fecha 5-7-71, el Juzgado deniega a los recurrentes la solicitud de ser parte en el proceso por no tener legitimación pasiva de acuerdo a ley.

-Con fecha 9-7-71 Torres Claros y otros insisten en su pedido de ser considerados parte en el proceso, solicitando se les cite de oficio por ser trabajadores del fundo Huando.

- Con fecha 12-7-71 el juzgado decreta no haber lugar al pedido por ser este recurso idéntico al de fecha 5-7-71.

- Con fecha 30-7-71 se notifica al Juzgado por el Secretario del Tribunal Agrario que dicho Tribunal ha declarado infundada la queja contra la resolución de fecha 7-6-71. 
-Con fecha 12-8-71 el Juez pronuncia sentencia con el siguiente contenido:

1. Considerando:

1.1. Que el presente juicio es en esencia de puro derecho por lo que no son indispensables todas las instrumentales admitidas por el Juzgado.

1.2. Que no hubo proceso fenecido violando la R. D. 098/71/DGRA-AR el art. $228^{\circ}$ de la Constitución, porque dicho artículo está referido exclusivamente a procesos judiciales.

1.3. Que la DGRA careció de facultades para conocer el expediente de parcelación de Huando en vía de apelación porque los trabajadores carecian en dicho trámite de legitimación procesal, pero sí era competente en virtud del art. $112^{\circ}$ del Reglamento de Normas Generales de Procedimientos Administrativos.

1.4. Que el art. $2^{\circ}$ de la R.D. 098/71/DGRA-AR no ordenaba anular los asientos sino inscribir la Resolución en los Registros Públicos.

1.5. Que la R.D. $031 / 63 / \mathrm{DZ}$ era nula por dos razones:

1.5.1. La Resolución autorizaba a subparcelar cuatro lotes sin los requisitos de procedimiento vigentes.

1.5.2. Porque no se cumplía los requisitos legales en lo que a tamaño de las parcelas resultantes de la parcelación establecian las normas vigentes.

2. Fallo:

Declarando inf́undada la demanda.

- Con fecha 13-8-71 se notifica con cédula bajo cargo la sentencia al Procurador, la DGRA y Huando S. A.

-Con fecha 20-8-71 Huando interpone recurso de apelación contra la sentencia de 12-8-71, en los siguientes fundamentos:

1. Causales de nulidad en que incurre la sentencia apelada:

1.1. Frustración de defensa oral no decretada por el Juez a pesar de haber sido pedida con anterioridad y ordenado tener presente oportunamente por el Juzgado: art. 1085? inc. $13^{\circ}$ del Código de Procedimientos Civiles.

1.2. Vicios de prueba: hay expedientes que no fueron ofrecidos ni actuados de oficio y que fueron "tenidos a la vista al sentenciar": art. $1085^{\circ}$ inc. $6^{\circ}$ del Código de Procedimientos Civiles.

1.3. Se estima que es juicio de puro derecho cuando dicha connotación la da la litis contestatio $y$ no el juez. Además, el art. 19 del D. L. 18833 habla de "pruebas": art. 1085 inc. 13ㅇ del Código de Procedimientos Civiles.

1.4. El Juzgado no puede estimar que una prueba admitida en juicio es irrelevante para mejor resolver sin actuarla: art. $1085^{\circ}$ inc. $5^{\circ}$ y 69 del Código de Procedimientos Civiles y $3^{\circ}$ acápite del art. 1ํ del D. L. 18833.

1.5. Resolución sobre asuntos que no son del litigio: se hace una larga exposición sobre la nulidad de la R. D. 031/69/DZ cuando la causa versa sobre la nulidad de la R.D. 098/ 71/DGRA-AR: art. 1085 inc. 99 del Código de Procedimientos Civiles.

2. Fundamentos de la apelación:

2.1. Art. $228^{\circ}$ de la Constitución:

2.1.1. No puede admitirse que una norma valga por su propio enunciado sino por su ubicación sistemática.

2.1.2. Aunque los actos administrativos son en general revocables, hay algunos que no lo son: los que declaran derechos y los de los órganos administrativos con jurisdicción.

2.2. La DGRA era órgano incompetente para resolver:

2.2.1. Como reconoce el juzgador: la DGRA era absolutamente incompetente para resolver porque no pudo conocer el expediente ni en vía de apelación ni de oficio. 
2.2.2. Respecto al art. $112^{\circ}$ del D. S. 00667-JC la sentencia confunde "disposiciones de orden público" con el "interés público", conceptos que no pueden ser equiparables.

Dice el recurso textualmente al respecto: "Por agravio al interés público debe y sólo puede entenderse la afectación de un bien o de un derecho del Estado, que representa y encarna a la sociedad en su conjunto. Es la usurpación, la violación o el perjuicio para la "cosa pública" (res pública) en contraposición con la "cosa privada" (res privada)".

3. En consecuencia, se solicita al Tribunal Agrario declare la nulidad de la Sentencia de Primera Instancia $y$, en su defecto, la revoque.

-Con fecha 20-8-71 el Juzgado resuelve conceder la apelación en ambos efectos.

-Con fecha 10-9-71 el Fiscal emite dictamen sobre el proceso en los siguientes términos:

1. Errores de fondo de la sentencia:

1.1. Desconoce el principio de garantía procesal:

1.1.1. La R. D. 031/69/DZ había quedado consentida y terceros contrataron con confianza en ello. Admitir que puede anularse dicha resolución es perjudicar derechos de terceros y crear el desorden dentro del orden.

1.1.2. La sentencia se basa en el art. $112^{\circ}$ del D.S. 006-67-SC. Es verdad que la norma es oscura pero, entonces, debe recurrirse a la supletoria y ésta es el art. 228 de la Constitución. La DGRA dice que no se aplica por estar bajo el título de Poder Judicial. Sin embargo cabe recordar que el art. XXIII del Título Preliminar del Código Civil señala que los jueces no pueden dejar de administrar justicia por deficiencia de la ley. En tal caso deben aplicar los principios generales de derecho.

1.1.3. Hay lesión del interés público cuando se afecta a toda la colectividad y no a parte de ella.

1.2. La sentencia rompe el principio de jerarquia de las leyes.

En efecto, la sentencia da preferencia al D. S. 006-67-JC sobre la Ley de Reforma Agraia y Reglamentos. (Se prefiere no abundar sobre el punto según el mismo dictamen).

1.3. La sentencia desconoce la ley.

Según el art. 10 del D.S. 006-67-JC y la disposición final de la Ley 17716 , el procecedimiento se debia regir por normas especiales y sólo en su defecto por el Reglamento de Normas Generales de Procedimientos Administrativos. En Reforma Agraria hay normas especiales de procedimiento.

1.4. Principio de suyo grave para la Reforma Agraria.

El art. 60 del D. L. 17716 establece la irreversibilidad del procedimiento de afectación o de expropiación y la sentencia contraviene dicho principio.

\section{Errores de procedimiento.}

2.1. El proceso de impugnación no es de puro derecho.

Lo dice textualmente el D. L. 18833; lo acepta el juez al aceptar pruebas y, además, tal calificación debe hacerse luego de la réplica y/o dúplica, cuando el juez aprecia la naturaleza de la causa. Además, el juez no puede calificar de irrelevantes pruebas que no conoce.

2.2. La sentencia se pronuncia sobre hechos no controvertidos. No está en discusión la R. D. 031/69/DZ: art. $1074{ }^{\circ}$ inc. 1 ㅇ del Código de Procedimientos Civiles.

2.3. La sentencia no se apoya en el mérito del proceso:

2.3.1. El juez aplica de oficio el art. $112^{\circ}$ del Reglamento de Normas Generales de Procedimientos Administrativos olvidando que esa facultad es para usarse sólo en favor de campesinos.

2.3.2. El argumento del art. $112^{\circ}$ del Reglamento de Normas Generales de Proce- 
dimjentos Administrativos, aparece del escrito de la DGRA en este proceso y no de la R. D. impugnada (art. 1974웅 inc. 3 ? del Código de Procedimientos Civiles).

2.4. Actuación de pruebas sin citación de parte. Se ha tenido a la vista pruebas ni ofrecidas ni solicitadas de oficio (art. $1085^{\circ}$ inc. $6^{\circ}$ el Código de Procedimientos Civiles).

Por tanto, opina por la nulidad e insubsistencia de la sentencia recurrida.

-Con fecha 19-10-71 el Tribunal Agrario pronuncia sentencia en los siguientes términos:

1. Considerando:

1.1. Que la falta de informe oral no causa indefensión ni tiene como pena la nulidad por to que no es aplicable el art. 1085 inc. 13 ? del Código de Procedimientos Civiles.

1.2. Que el que se haya tenido a la vista los expedientes acumulados seguidos por los compradores de parcelas sin ser ofrecidos $u$ ordenados de oficio en calidad de prueba no perjudica a Huando por lo que es aplicable el tercer párrafo del art. $166^{\circ}$ del D. L. 17716 (Texto Unico Concordado).

1.3. Que el juzgador está autorizado para prescindir al sentenciar de pruebas instrumentales ofrecidas y admitidas si considera que no son imprescindibles y si ha hecho las gestiones necesarias para obtenerlas, máxime si tiene plazos para administrar justicia y si las pruebas no actuadas son ajenas al caso.

1.4. Que no se ha tramitado el expediente como de puro derecho sino de acuerdo al D.L. 18833.
1.5. Que la parte resolutiva de la sentencia se pronuncia sólo sobre la validez de la R.D. 098/71/DGRA-AR que es materia de este proceso.

1.6. Que el art. $112^{\circ}$ del Reglamento de Normas Generales de Procedimientos Administrativos es un principio general de Derecho Administrativo que no puede desconocer ninguna ley o reglamento especial porque el acto administrativo con vicio de nulidad no puede convalidarse ni por falta de recurso ni por transcurso del tiempo.

1.7. Que los conceptos de "interés público", "utilidad pública" y "necesidad pública" responden a imperativos de justicia y a exigencias socio-económicas de la sociedad donde se aplican.

1.8. Que de los artículos $1^{\circ}$ y $2^{\circ}$ del Decreto Ley 17716 se desprende que la Reforma Agraria persigue la justicia social en el campo y forma parte de la política nacional de desarrollo, lo que interesa a toda la colectividad y no sólo a un sector o grupo y por tanto la parcelación de cualquier fundo es acto de interés general por lo que la violación de las normas de Reforma Agraria causan manifiesto agravio al Interés público.

1.9. Que la R. D. 098/71/DGRA-AR no dispone la inscripción de nulidad de parcelación en los Registros Públicos.

2. Confirmaron la apelada.

- Con fecha 25-10-71, por orden del Presidente del Tribunal Agrario, el relator-secretario devuelve los autos al Juez de Tierras que conoció en Primera Instancia.

- Con fecha 25-10-71 el Juez de Tierras decreta: "Por devueltos, cúmplase to ejecutoriado".

En efecto, la sentencia de preferencia al D 